\title{
SCC and conventional concrete on site: Property assessment
}

\section{Caracterização das propriedades do betão em elementos produzidos com BAC e betão convencional}
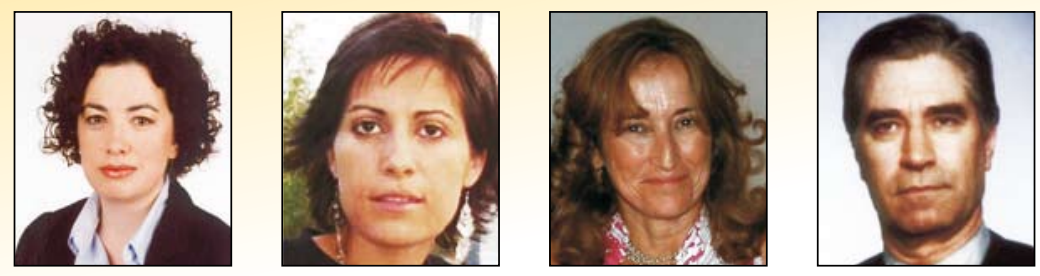

S. NUNES a

snunes@fe.up.pt

H. FIGUEIRAS

helena.figueiras@fe.up.pt

J. SOUSA COUTINHO' jcouti@fe.up.pt

J. FIGUEIRAS d jafig@fe.up.pt

\begin{abstract}
The present paper deals with comparing properties of hardened SCC cast during first full-scale tests in a precast factory and similar conventional concrete currently used in the same factory. The main goal was to evaluate viability of replacing the C45/55 conventional concrete, in use at the precast factory, by a SCC of the same class of resistance and maintaining the constituent materials. A wide number of specimens (cubes, cylinders, prisms) and full size precast elements were cast with both SCC and conventional vibrated concrete to enable comparing different properties of both types of hardened concrete. In order to implement SCC in this precast factory, suitability of actual current processes involved in production, mixing, transport and placing had to be evaluated. SCC exhibited improved mechanical behavior, higher resistance to fluid ingress and a more uniform strength along the full-size element due to a combination of proper mixdesign together with controlled mixing and placing on site.
\end{abstract}

Keywords: Self-compacting concrete (SCC); conventional concrete; precast industry; mechanical properties; durability.

\section{Resumo}

O presente artigo apresenta uma comparação das propriedades do betão endurecido em elementos produzidos com betão auto-compactável (BAC) e betão convencional durante ensaios à escala real levados a cabo numa fábrica de pré-fabricação. O principal objectivo deste estudo consistiu em avaliar a viabilidade da substituição do betão convencional C45/55, em uso na fábrica de pré-fabricação, por um BAC da mesma classe de resistência e mantendo os mesmos materiais constituintes. Durante os ensaios à escala real foram betonados diversos provetes (cubos, cilindros e prismas) e elementos pré-fabricados com ambos os tipos de betões destinados à caracterização do betão endurecido. Tendo em vista a aplicação do BAC nesta fábrica de pré-fabricação avaliou-se ainda a adequabilidade dos processos correntes envolvidos na produção, amassadura e transporte do betão. O BAC apresentou um comportamento mecânico melhorado, maior resistência ao ingresso de fluídos e uma distribuição mais uniforme da resistência ao longo dos elementos pré-fabricados, o que resultou da combinação de uma composição adequada com o controle dos processos de amassadura e colocação do betão.

Palavras-chave: Betão auto-compactável (BAC); betão convencional; indústria de pré-fabricação; propriedades mecânicas; durabilidade

\footnotetext{
LABEST, Faculty of Civil Engineering, Porto University, snunes@fe.up.pt, Rua Dr. Roberto Frias, 4200-465 Porto, Portugal, Fax (+351) 225081835

LABEST, Faculty of Civil Engineering, Porto University, helena.figueiras@fe.up.pt, Rua Dr. Roberto Frias, 4200-465 Porto, Portugal

LABEST, Faculty of Civil Engineering, Porto University, jcouti@fe.up.pt, Rua Dr. Roberto Frias, 4200-465 Porto, Portugal

LABEST, Faculty of Civil Engineering, Porto University, jafig@fe.up.pt, Rua Dr. Roberto Frias, 4200-465 Porto, Portugal
} 


\section{Introduction}

Today, along with requirements related to hardened concrete concerning strength and durability, increasing demands related to fresh concrete have emerged, as is the case of self-compacting concrete (SCC). In the last few years, there has been a growing interest on SCC technology among the main constructors and construction industry. The principal reasons for this interest concern the ease of placing this type of concrete in heavily reinforced areas difficult to access, the reduced effort in accomplishing some of the tasks and the significant reduction of the construction period. Along with these advantages, in terms of environment, this technology will enable considerable reduction of acoustic noise levels and promote use of secondary raw materials [1] [2].

In particular, precast industry is specially suited for the use of SCC. In a precast factory, concrete elements with a complex geometric shape and dense reinforcement are often produced. The production of such elements using traditional vibrated concrete can only be executed with great effort; very strong external vibrators have to be mounted and in some cases casting has to be carried out in more than one step. When consolidation is incomplete the resulting concrete elements with defects have to be repaired, causing further delay and increase in cost. Vibration has also harmful physical impact on workers.

SCC requires a reliable control of materials characteristics, mixing process and transportation [3]. In a precast plant it is easier to install quality control systems because of the high degree of automation and repetition of similar processes. Besides, the production process is less influenced by weather conditions and transport time is shorter so retaining fluidity is usually not a problem.

Often, in the precast industry strength at early age becomes the dominant requirement due to the need of applying pre-stress or demoulding a few hours after casting. This leads to conventional concrete mixtures with very low water/cement ratio, including strong action superplasticizers and a cement content closer to that required for the powder-type SCC [4]. Considering this type of mixture as a basis, to obtain a SCC mixture, the paste content (including mineral additions and the superplasticizer dosage) has to be increased and the coarse aggregate content must be reduced [3]. The "excess paste" should be the minimal quantity to create a "lubricating" layer around the aggregate particles and reduce the inter-particle friction necessary to achieve self-compactability [5]. Minimum paste content is of interest for both economical and material performance reasons.

The present study aims at comparing properties of hardened SCC and conventional concrete, both produced under actual conditions at a precast factory. Mechanical and durability related properties were assessed using concrete specimens cast on site. Cores drilled from different parts of two box-culvert elements, one cast with SCC and the other with similar conventional concrete were used to evaluate uniformity of compressive strength and the transport properties of the near-surface concrete. Suitability of actual current processes involved in production, mixing transport and placing of SCC is also discussed.

\section{SCC laboratory study}

\subsection{Materials characterization}

Crushed calcareous aggregate $(1-12.5 \mathrm{~mm})$, siliceous natural fine sand (sand 1) with a fineness modulus of 2.52 and a natural coarse sand (sand 2) with a fineness modulus of 3.27 were used, see Figure 1. The

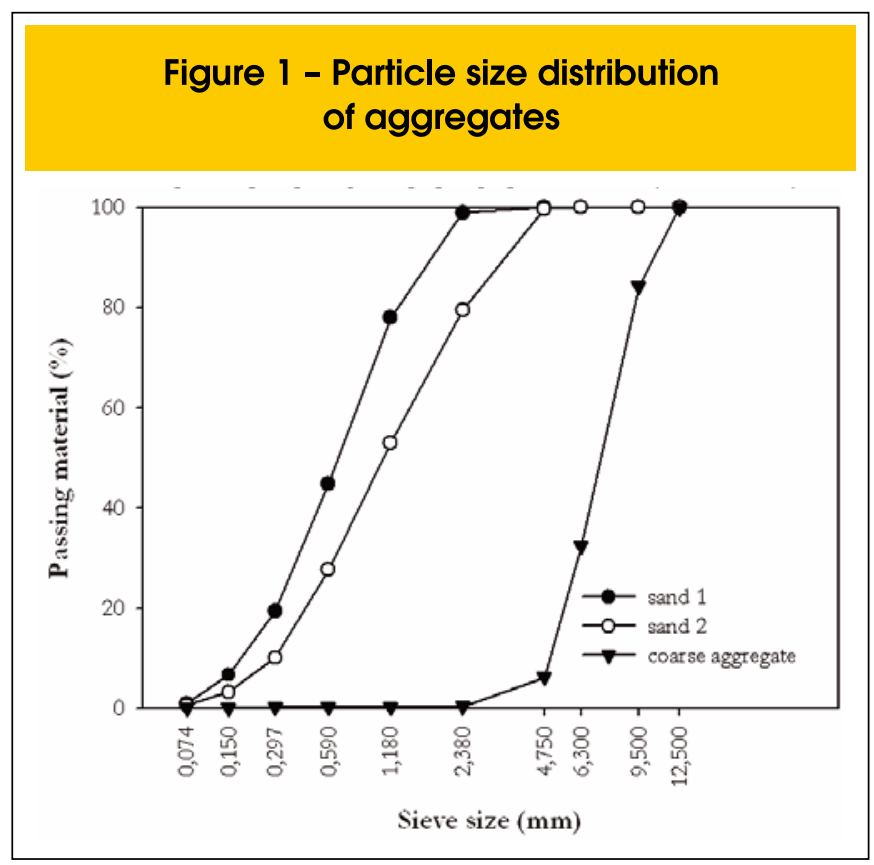

specific gravity of the coarse aggregate, sand 1 and sand 2 were 2.61 , 2.60 and 2.62 , and absorption values $1.29 \%, 0.68 \%$ and $0.51 \%$, respectively, according to EN 1097-6. In this application a SCC mix was prepared with Portland cement (CEM I $52.5 \mathrm{R}$ ) and a mineral addition (limestone filler), with values for specific gravity of 3.12 and 2.70, respectively. The specific surface (Blaine) and the mean particle size of limestone filler were $5150 \mathrm{~cm}^{2} / \mathrm{g}$ and $4.52 \mu \mathrm{m}$, respectively. A polycarboxylate type superplasticizer of specific gravity of 1.05 and $18.5 \%$ solid content was used. All of these materials were being used in the production of conventional concrete at the precast factory, except for the superplasticizer.

\subsection{SCC mix-design}

A key phase when producing SCC lies on the design of mix proportions so as to obtain adequate properties of fresh concrete. SCC in the fresh state must show filling ability, resistance to segregation and passing ability [3]. Several mix design techniques have been proposed and some general recommendations can be taken into account for SCC proportioning [3] which mainly consist of limiting the coarse aggregate volume and maximum aggregate size, using low water powder ratio and a superplasticizer. Based on the Japanese SCC-designing method, the mix-design method used consisted on a two level (mortar and concrete) optimization method and is described more in detail in [6]. At mortar level, mortar flow and funnel tests [6] were carried out to study the relation between the two sands (fine aggregate was a combination of two sands) along with paste volume and volumetric water/powder ratio. The mortar properties adequate for SCC are sufficiently well defined at this level [6] and if target values are achieved, in the next stage, tests on concrete, although essential, shall be reduced to a minimum. A more comprehensive procedure for the design of mortar mixtures which are adequate for SCC can be found in [7].

Final trials at concrete level were necessary to quantify the amount of coarse aggregate, to adjust superplasticizer dosage (if neces- 
sary) and to confirm self-compactability of the designed concrete. Slump-flow, V-funnel and Box tests were used to characterize SCC in the fresh state, see Figure 2. The Slump-flow test is used to evaluate deformation capacity, viscosity and also resistance to

Figure 2 - Equipment used in the (a) Slump-flow, (b) V-funnel and (c) Box tests (3)

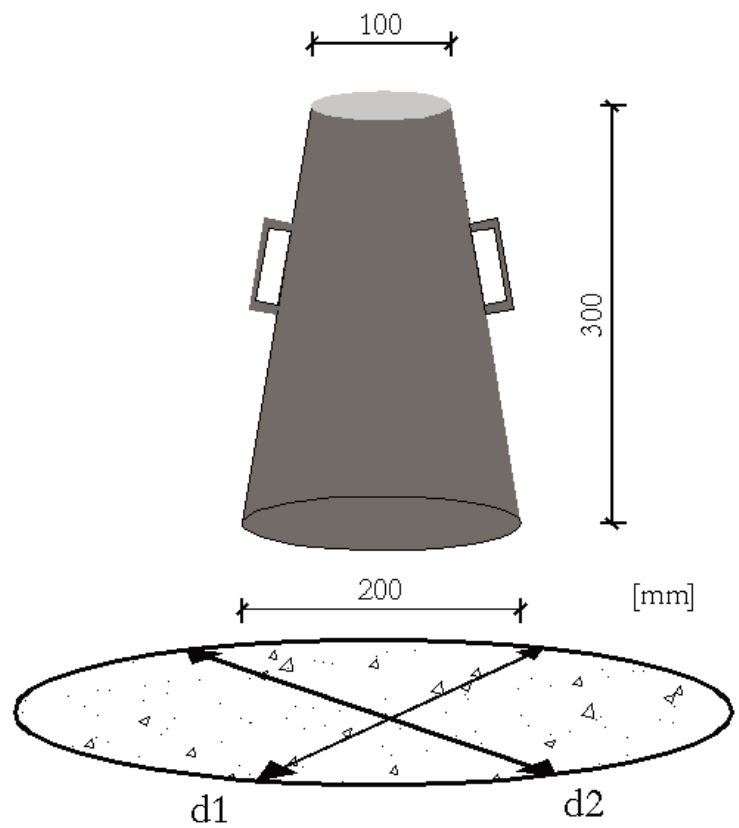

(a)

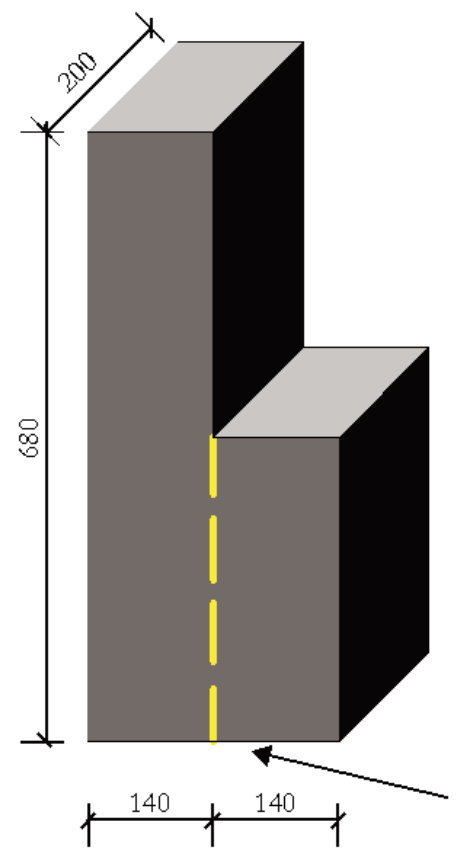

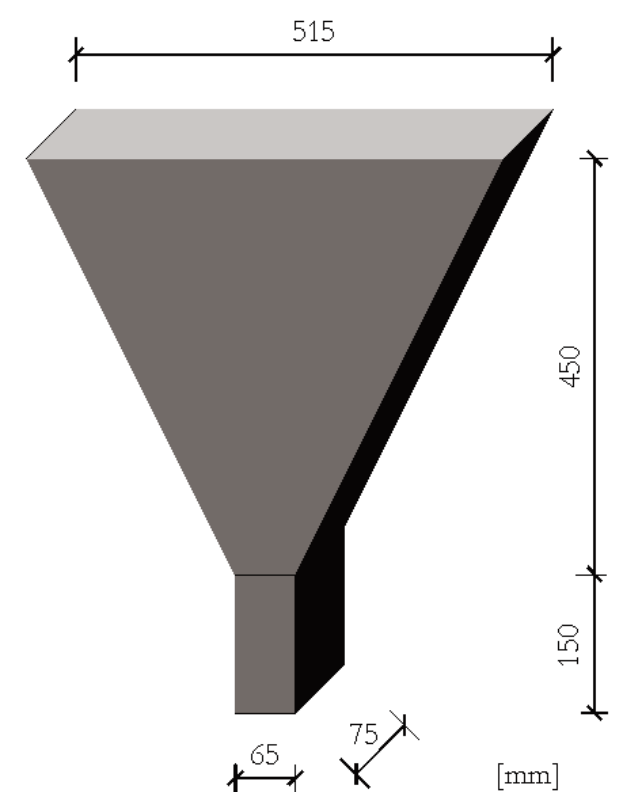

(b)

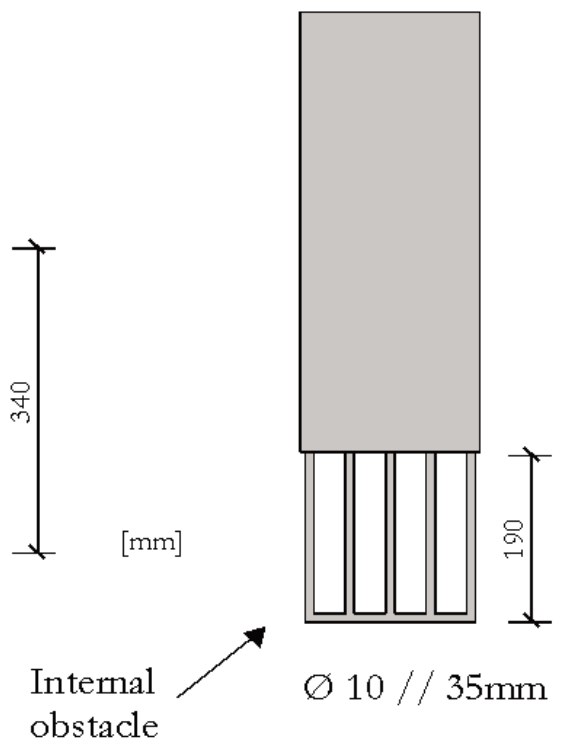

(c) 
segregation of SCC by visual observation. This test enabled recording final slump flow diameter (Dflow) and time necessary for concrete to reach a $50 \mathrm{~cm}$ diameter (T50). The V-funnel test is used to assess viscosity and passing ability of SCC and this test enabled recording flow time (Tfunnel). With the Box test it is possible to assess ability of concrete to pass through tight openings between reinforcing bars and filling ability. This test enabled recording filling height $(\mathrm{H})$. Further details of the equipment used for testing fresh concrete and test procedures used can be found in [3], [8]. Typical acceptance criteria for SCC are Dflow from 600 to $750 \mathrm{~mm}$, T50 from 2 to $5 \mathrm{~s}$, Tfunnel from 6 to $12 \mathrm{~s}$ and $\mathrm{H}$ higher than $300 \mathrm{~mm}$. However, according to European standards which are being established specifically for SCC values outside these ranges may be acceptable depending on the application type and/ or site requirements [9].

\subsection{Mixing sequence, mix proportions and test results}

Mixes were prepared in the laboratory in 25 litres batches and mixed in an open pan mixer. The mixing sequence consisted of mixing both sands and coarse aggregate with one quarter of the mixing water during 2.5 minutes, waiting for 2.5 minutes for absorption, adding of the powder materials, followed by the rest of the water with the superplasticizer and finally mixing concrete during 8 minutes, additionally. Slump-flow, V-funnel and Box tests were then carried out to characterize fresh state. Final SCC mix proportions are presented in Table 1 along with test results on fresh concrete. The amount of water in Table 1 includes the absorption water of aggregates and accounts for the water included in the superplasticizer. This mixture exhibited good deformability, without blocking, and enough viscosity to avoid segregation.

\section{Table 1 - Final lab SCC mix proportion and fresh concrete tests results}

\begin{tabular}{|cc|}
\hline Constituent materials & $\left(\mathrm{kg} / \mathrm{m}^{3}\right)$ \\
cement & 379 \\
limestone filler & 192 \\
sand 1 & 600 \\
sand 2 & 202 \\
coarse aggregate & 810 \\
water & 154 \\
superplasticizer (liquid) & 13.2 \\
water/cement & 0.43 \\
water/binder & 0.29 \\
Fresh concrete test results \\
Dflow (mm) & 645 (at 15 minutes) \\
T50 (sec.) & 2.8 (at 15 minutes) \\
Tfunnel (sec.) & 10.1 (at 20 minutes) \\
H (mm) & 335 (at 25 minutes) \\
\hline
\end{tabular}

Figure 3 - Reinforcement in the I-beam element selected for the full-scale tests

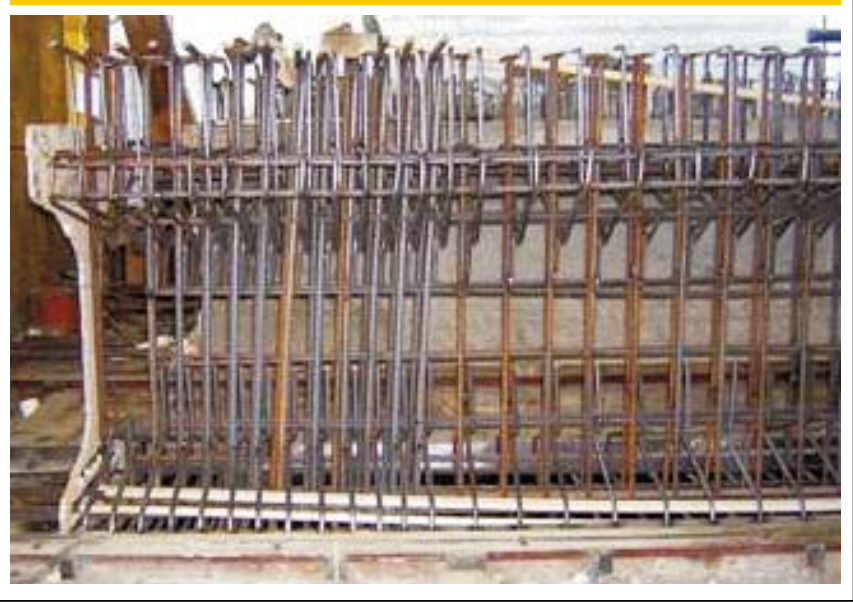

After testing fresh concrete, six standard $150 \mathrm{~mm}$ cubes were moulded to evaluate 7 and 28 day compressive strength. Concrete cubes were demoulded one day after casting and kept inside a chamber under controlled environmental conditions (Temp. $=20^{\circ} \mathrm{C}$ and $\mathrm{HR}=100 \%$ ) until testing for compressive strength at the specified ages. The mean value compressive strength, for cubes, evaluated at 7 and 28 days were 55 and $69 \mathrm{MPa}$, respectively.

\section{Full scale tests: fresh concrete}

\subsection{Selected elements}

The selected elements for full scale testing were a $3.0 \mathrm{~m}$ part long of a I shaped beam (Figure 3 ) and a box-culvert (length $=2.5 \mathrm{~m}$; height $=1.15 \mathrm{~m}$; width $=2.32 \mathrm{~m}$; wall thickness $=0.15-0.20 \mathrm{~m}$ ) (Figure $4)$. The beam element with a complex geometric shape also includ-

\section{Figure 4 - Reinforcement in the box-culvert selected for the full-scale tests}

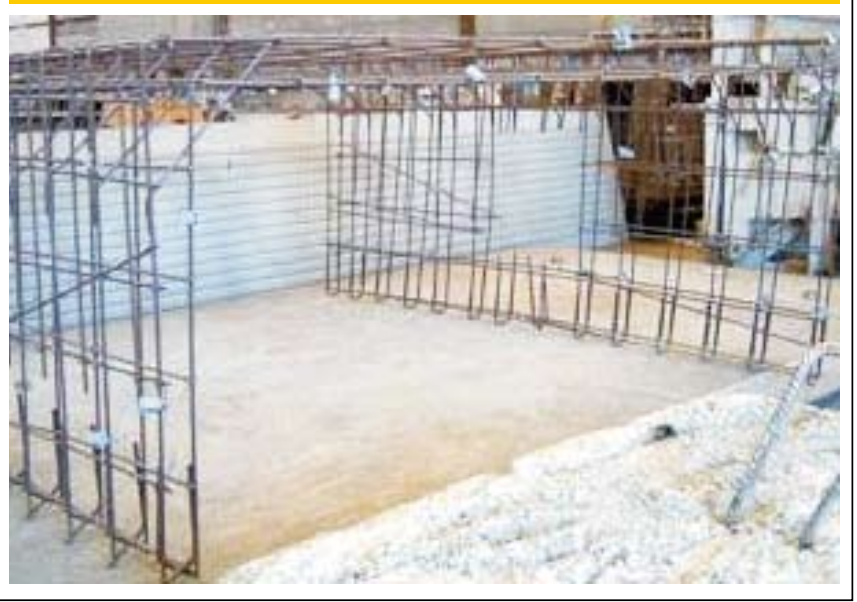




\section{Table 2 - Mix proportions of SCC and conventional concrete produced during full-scale tests}

\begin{tabular}{lcc|} 
Constituent materials & $\begin{array}{c}\text { SCC } \\
\left(\mathrm{kg} / \mathrm{m}^{3}\right)\end{array}$ & $\begin{array}{c}\text { CONV } \\
\left(\mathrm{kg} / \mathrm{m}^{3}\right)\end{array}$ \\
cement & 387 & 350 \\
limestone filler & 197 & 85 \\
sand 1 & 613 & 407 \\
sand 2 & 206 & 413 \\
coarse aggregate & 826 & 938 \\
water & 139 & 171 \\
superplasticizer (liquid) & 12.9 & $3.70^{*}$ \\
water/cement & 0.39 & 0.50 \\
water/fines & 0.26 & 0.40 \\
* a different superplasticizer was used for conventional concrete
\end{tabular}

ed an anchorage zone with highly dense reinforcement, see Figure 3. When casting this sort of element with conventional vibrated concrete very strong external vibrators have to be mounted. To enable drilling cores from the box-culvert for further testing, three zones with no reinforcement were planned, one in the centre of each side and the third on the slab, as shown in Figure 4. Similar elements were cast with both SCC and conventional concrete.

\subsection{Mixing, transport and placement}

Previous full-scale testing [10] had shown substantial differences concerning behavior of fresh concrete produced in the laboratory and then on site. Possible causes were: mixing efficiency; consistency variations over time; inaccuracy in weighing materials; mistakes in determining moisture of aggregates and also deviations in materials used. Full scale testing was carried out in winter, at Maprel precast factory under normal working conditions. The paddle-mixer at the factory has a maximum capacity of two cubic meters. The mixing procedure used was the same as for conventional concrete except for increased mixing time, about two times longer. Considering the higher mixing efficiency at the factory compared to mixing in the laboratory and taking into account possible misestimates of aggregate moisture, the water content and superplasticizer dosage were both reduced so as to produce concrete less prone to segregation, based on current knowledge and practice. As a consequence the water/cement ratio for factory produced SCC was lower than the lab SCC (see Table 1) and both of these were lower than the conventional concrete mixture (see Table 2). The measured moisture content for coarse aggregate, sand 1 and sand 2 were $0.5 \%, 6.5 \%$ and $6.0 \%$, respectively. Mix proportions for both SCC and similar conventional concrete are presented in Table 2. Results concerning fresh SCC testing were Dflow $=565$ $\mathrm{mm}, \mathrm{T} 50=5.6 \mathrm{~s}$, Tfunnel=14.9 $\mathrm{s}$ and $\mathrm{H}=340 \mathrm{~mm}$. These results show that changes made in mix-proportions (see Tables 1 and 2) had a stronger effect on SCC workability than the change in mixing energy. The water content and superplasticizer dosage are often found to exhibit a strong effect on SCC fresh state properties [11].
As expected, both a reduction of water content and a reduction of superplasticizer dosage led to lower deformability and/or increased viscosity of SCC mixtures. The mixture exhibited good filling ability, high segregation resistance and enough deformability for this type of application. SCC filled up the entire mould, completely enclosing the reinforcement. After stripping the formwork only a few air bubbles were visible on the horizontal parts. The main differences between mix proportions of the SCC and conventional concrete, as can be observed in Table 2, concern coarse aggregate, powder materials and the superplasticizer. These differences lead to higher cost of materials for SCC, about $18 \%$ higher.

The motor vehicle, shown in Figure 5, used to transport concrete from the mixer to the casting area includes an endless screw which drives concrete upwards from the tank and then discharges it into the formwork. This system presented several limitations such as the discharge height permitted, smaller than the elevation required for larger box-culvert moulds also handled in this factory. Conversely, if the mould is smaller, concrete drops from a high distance and air is entrapped during the fall. Another relevant limitation concerns the capacity of the tank which is smaller than the maximum capacity of the mixer. In fact this can delay SCC production since no waiting period for vibration is required as when using conventional concrete.

Conventional concrete elements were externally vibrated and as vibration is eliminated for SCC, for production of these elements work on site was far lighter and noise reduced. Environment on site was improved considerably with the use of SCC leading to a very positive attitude among workers and engineers.

\subsection{Discussion}

One of the main advantages of SCC is increased productivity. However, the construction site layout has to be optimized to achieve a more competitive production and reduce costs, in particular costs related to materials, to increased mixing time and to quality control [11]. Production capacity and casting capacity on site should be balanced off so as to ensure that SCC is placed without breaks in supply and within flowability retention time. Discontinued SCC production will affect filling ability and may result in unwanted lift

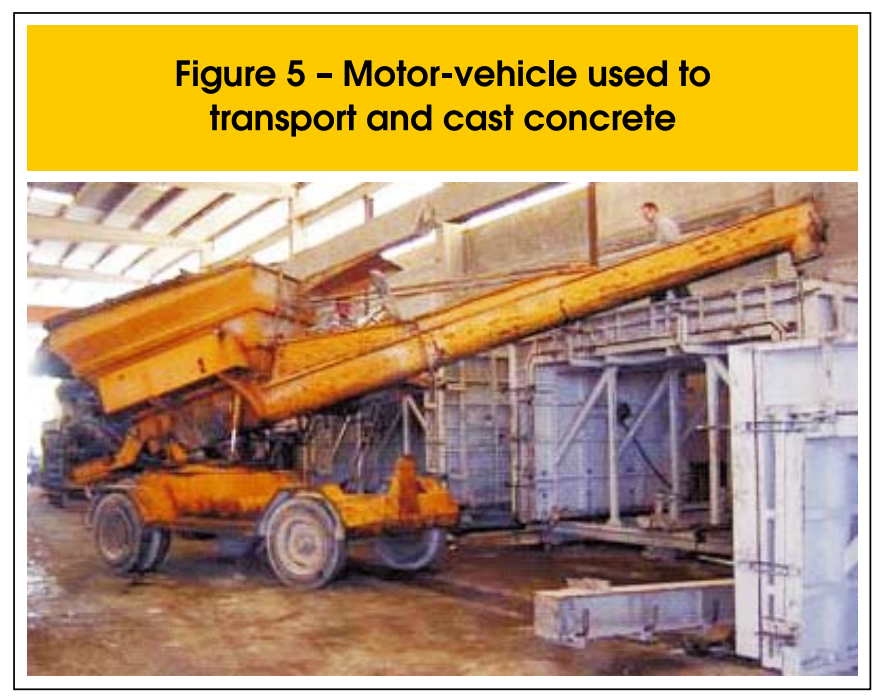




\section{Figure 6 - I-shaped beam cast with SCC}

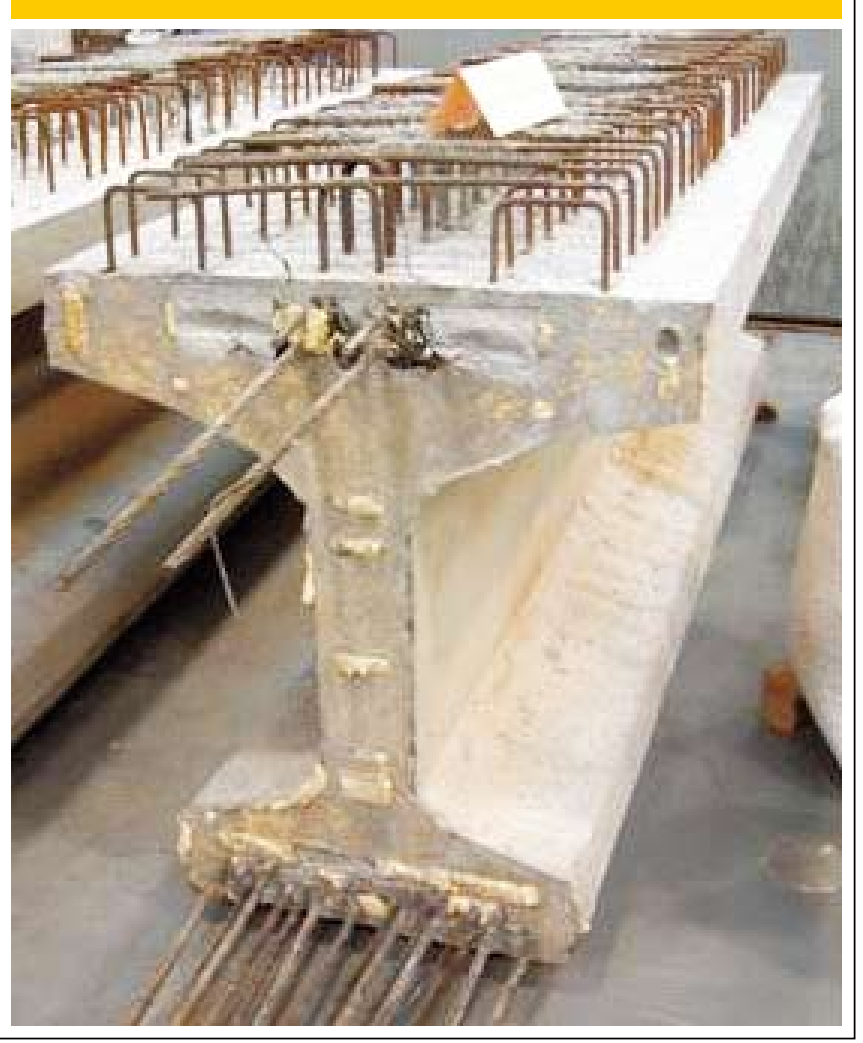

lines on vertical surfaces as well as possible bonding problems between layers. As mentioned before, full-scale tests carried out at Maprel precast factory demonstrated that for SCC to be placed in one continuous pour, installations and equipment set for conventional concrete had to be adjusted. It was also recommended that workers involved should be specially trained.

\section{Full scale tests: hardened concrete}

After casting the full size precast elements (see Figure 6) a large number of specimens (cubes, cylinders, and prisms) were also produced both with SCC and conventional vibrated concrete thus enabling comparing hardened concrete. SCC and conventional concrete specimens were demoulded six and four days after casting, respectively, and kept inside a chamber under controlled environmental conditions (Temp. $=20^{\circ} \mathrm{C}$ and $\mathrm{HR}=100 \%$ ) until testing. Demoulding was carried out later one day because the specimens had to be transported from the precast factory to the laboratory at the Faculty and these were kept in the moulds until the arrival at the Faculty. Furthermore, SCC and conventional concrete elements were cast two days apart; this explains the difference in the period to demoulding of SCC and conventional concrete specimens.

\subsection{Mechanical properties}

Development of compressive strength, tensile splitting strength, tensile flexural strength and Young's modulus for both SCC and conventional concrete is shown in Table 3, where the mean value is presented, followed by the coefficient of variation in brackets. In spite of the lower coarse aggregate content, generally, SCC exhibited improved mechanical properties due to the lower water/ cement ratio. Some of these results present high dispersion, especially those of conventional concrete, which may explain why, in some cases, compressive strength did not increase with age. This is probably associated to bad concrete sampling and improper compaction, in the case of conventional concrete. In some of the conventional concrete specimens it was possible to clearly identify the zone where the poker was used, i.e. a central zone with missing aggregates was observed (see Figure 7). On the contrary, a uniform distribution was observed in the SCC specimens (see Figure 8).

In-situ compressive strength at about 60 days was obtained from cores drilled from different parts of the box-culverts such as the central areas of the sides (wall-A and wall-B) and slab, see Figure 9. Cores drilled from the sides were loaded perpendicular to the casting direction whereas slab cores were loaded parallel to casting direction. The diameter of these cores was $94 \mathrm{~mm}$ and the height/diameter ratio $(\mathrm{h} / \mathrm{d})$ of cores varied between 1.58 and 1.72 . Core strength was converted to the strength of corresponding standard cylinders $(\mathrm{d}=150 \mathrm{~mm} ; \mathrm{h}=300 \mathrm{~mm})$ using the relations presented by Mansur [12], dependant on the level of strength ranging from 20 to $100 \mathrm{MPa}$. Converted values from the mean compressive strength as well as the specific gravity results for both SCC and conventional concrete box-culvert elements are presented in Table 4. The lower strength obtained for cores (60 days) compared to moulded specimens (28 day cylinders, Table 3 ) can be explained by different curing conditions as the box-culvert elements were dry cured. Compressive strength and specific gravity results were consistent throughout the SCC box-culvert whereas for the conventional concrete box-culvert compressive strength and specific gravity decreased considerably in the slab, due to lack of efficient compaction in the upper part of the mould. Therefore SCC led to a more homogeneous and isotropic material along the box-culvert.

\subsection{Durability}

Transport properties of the near-surface concrete, which play a major role in durability of reinforced concrete, are controlled by three mechanisms, namely, capillary absorption, permeability and diffusion [13], [14]. Usually, the more resistant concrete is to the ingress of aggressive agents (pure water or carrying ions, oxygen and carbon dioxide) the more durable it will be [13]. In the present study water absorption by capillarity and two chloride migration tests were carried out to assess concrete durability.

To consider ability of near-surface concrete to absorb and transmit water by capillary action the RILEM TC116-PCD recommendation was adopted and modified [15], [16]. The moulded side faces of $150 \mathrm{~mm}$ cube specimens were tested, instead of the moulded bottom face of $150 \mathrm{~mm}$ cube specimens used in the RILEM recommendation, so that two specimens could be obtained from each cube. This test was also undertaken on each moulded face of 75 days old cores (diameter $=150 \mathrm{~mm}$; thickness $=50 \mathrm{~mm}$ ) taken from the wall parts of the box-culvert elements. All specimens (thickness $=50 \mathrm{~mm}$ ) were allowed to dry in a ventilated heater at $40^{\circ} \mathrm{C}$ until constant mass. After cooling, the specimens were prepared and tested according to the RILEM recommendation. The uptake 
Table 3 - Mechanical properties of cast concrete specimens

\begin{tabular}{|lcccc|}
\hline Concrete property & age of concrete & $\begin{array}{c}\text { number of } \\
\text { specimens }\end{array}$ & scC & CONV \\
\hline Compressive strength*(MPa) & 7 days & 6 & $67.3(3 \%)$ & $64.4(3 \%)$ \\
& 10 days & 6 & $69.8(7 \%)$ & $66.5(6 \%)$ \\
& 14 days & 6 & $66.8(8 \%)$ & $60.3(15 \%)$ \\
& 28 days & 6 & $71.4(8 \%)$ & $66.2(10 \%)$ \\
Compressive strength** (MPa) & 7 days & 3 & $68.4(2 \%)$ & $61.6(4 \%)$ \\
& 28 days & 2 & $76.5(--)$ & $70.4(--)$ \\
Tensile splitting strength** $(\mathrm{MPa})$ & 7 days & 3 & $4.4(19 \%)$ & $4.9(2 \%)$ \\
& 10 days & 3 & $5.8(3 \%)$ & $4.8(9 \%)$ \\
& 14 days & 3 & $5.6(4 \%)$ & $4.7(18 \%)$ \\
& 28 days & 3 & $5.7(6 \%)$ & $4.9(11 \%)$ \\
Tensile flexural strength*** $(\mathrm{MPa})$ & 7 days & 2 & $4.3(--)$ & $4.2(--)$ \\
& 14 days & 2 & $5.0(--)$ & $4.4(--)$ \\
& 28 days & 2 & $5.0(--)$ & $4.6(--)$ \\
Young's modulus** $(\mathrm{GPa})$ & 7 days & 3 & $41.5(1 \%)$ & $42.9(1 \%)$ \\
& 10 days & 3 & $42.6(1 \%)$ & $42.7(2 \%)$ \\
& 14 days & 3 & $44.1(1 \%)$ & $43.2(2 \%)$ \\
& 28 days & 3 & $44.9(1 \%)$ & $43.1(2 \%)$ \\
& & &
\end{tabular}

\section{Figure 7 - Distribution of coarse aggregate in a conventional concrete specimen}

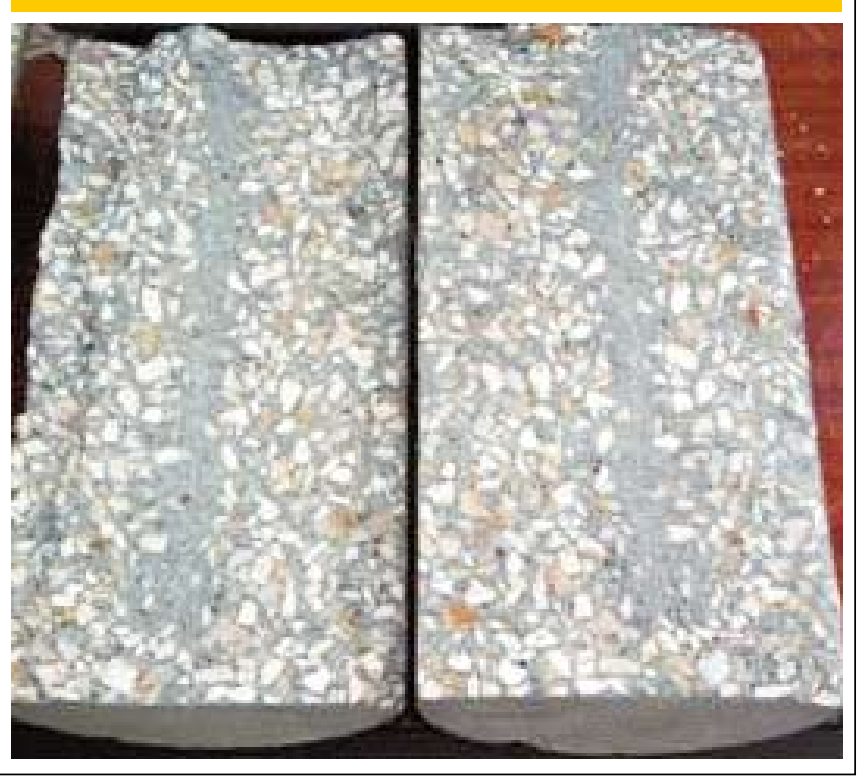

of water by capillary absorption was measured through the weight gain of each specimen at time intervals of $10 \mathrm{~min}, 0.5 \mathrm{~h}, 1 \mathrm{~h}, 4 \mathrm{~h}, 18 \mathrm{~h}$ and 24 hours of contact water [16]. The absorption of water into concrete under capillary action is dependent on the square-root of time and may be modeled by the following equation [14]:

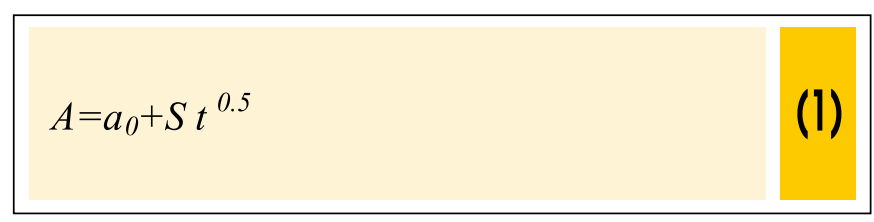

where $A\left(\mathrm{~g} / \mathrm{m}^{2}\right)$ is the water absorption by unit area since the moment the specimen was dipped in a few millimeters of water, $S$ is the "Sorptivity" of the material, $t$ is the elapsed time and $a_{0}\left(\mathrm{~g} / \mathrm{m}^{2}\right)$ is the water absorbed initially by pores in contact with water. Testing each specimen led to the linear relations presented in Figure 10. The corresponding model parameters and correlation coefficients are presented in Table 5. Results of cube specimens show that the rate of capillary absorption, indicated by the "Sorptivity" parameter is slightly lower for SCC, compared to conventional concrete. Comparing "Sorptivity" of cube specimens and of cores taken from the box-culvert elements results indicate that the rate of capillary absorption is between 2 and 3 times higher for cores for both SCC and conventional concrete. Furthermore, a larger variation of re- 


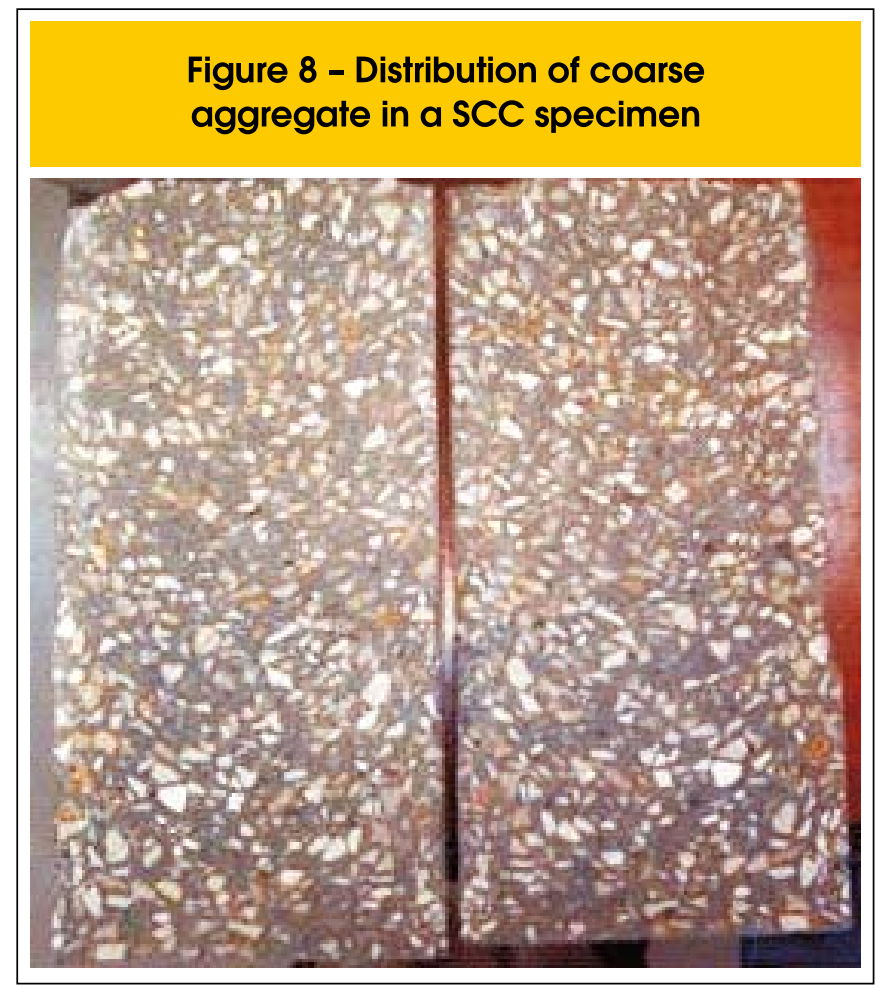

sults was found with cores. This might be explained by the influence of surface porosity in the box-culvert elements and/or any surface defects induced by the drilling machine.

Resistance to chloride penetration was assessed following ASTM C1202 [17] and the NORDTEST method [18]. This last method has recently been adopted in Portugal as the standard method for resistance to chloride penetration [19]. Cube specimens (51 to 54 day old) were used and cores of approximately $100 \mathrm{~mm}$ diameter were drilled out and sawn in three parts; the top $50 \mathrm{~mm}$ discs corresponding to opposite moulded faces $X$ and $Y$ were used for the ASTM C1202 test and for the NORDTEST method, respectively. Cores (diameter $=100$ $\mathrm{mm}$ ) drilled from the box-culvert elements were also tested (90 to 100 old) to assess the influence of curing conditions. The conditioning of the concrete disc specimens for both test procedures consisted of: 1 hour air drying; 3 hours vacuum (pressure $<600 \mathrm{~mm} \mathrm{Hg}$ ); 1 hour of

\section{Figure 9 - Box-culvert element and location of test cores in the lateral wall-A}

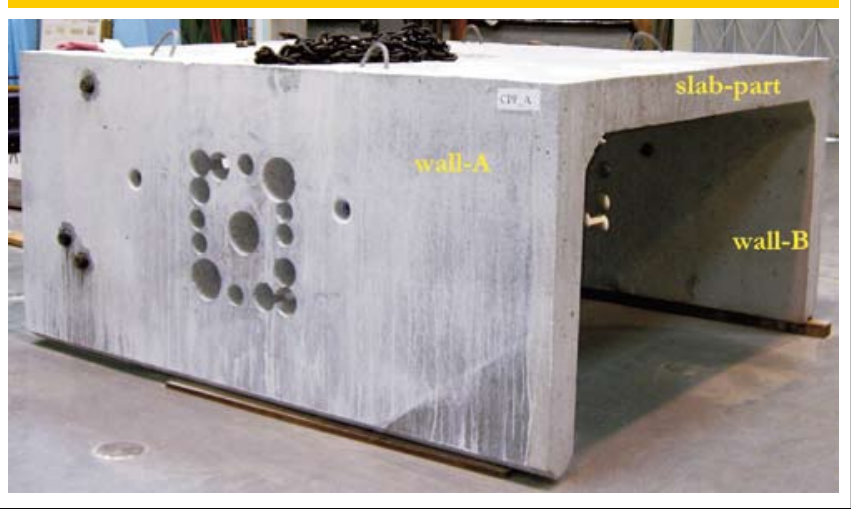

additional vacuum with specimens under deaerated water, followed by 18 hours of soaking in water for the ASTM test and soaking in saturated calcium hydroxide solution for the NORDTEST method.

The method described in the ASTM C1202 consists of monitoring the amount of electrical current passed through an approximately $100 \mathrm{~mm}$ diameter by $50 \mathrm{~mm}$ thick concrete specimen when a potential difference of $60 \mathrm{~V}$ is maintained across the specimen for a period of six hours. Chloride ions are forced to migrate out of a $\mathrm{NaCl}$ solution subjected to a negative charge, through the concrete into a $\mathrm{NaOH}$ solution maintained at a positive potential. The total charge passed, in coulombs, is used as an indicator of the resistance of the concrete to the ingress of chloride ions. Results of this test are presented in Table 6 and Table 7 for cube specimens and core samples taken from box-culvert elements, respectively.

The NORDTEST method is a non-steady state migration method based on a theoretical relation between diffusion and migration, which enables the calculation of the apparent chloride diffusion coefficient from an accelerated test [18]. It is based on measuring the depth of colour change of a silver nitrate solution sprayed on the specimens previously submitted to a migration test (disc specimens were submitted to an electrical current corresponding to a potential difference of $30 \mathrm{~V}$, during 24 hours). Results of this test are also presented in Table 6 and Table 7, respectively, for cube specimens

Table 4 - Converted compressive strength of cores (60 days) and specific gravity

\begin{tabular}{|lcccc|}
\hline Concrete property & location & $\begin{array}{c}\text { number } \\
\text { of colors }\end{array}$ & SCC & CONV \\
Compressive strength (MPa) & wall-A & 6 & $67.8(3 \%)$ & $67.3(3 \%)$ \\
& wall-B & 6 & $69.7(3 \%)$ & $66.3(5 \%)$ \\
Specific gravity $\left(\mathrm{kg} / \mathrm{m}^{3}\right)$ & slab part & 6 & $70.7(7 \%)$ & $58.1(8 \%)$ \\
& wall-A & 6 & $2339(1 \%)$ & $2380(2 \%)$ \\
& wall-B & 6 & $2329(1 \%)$ & $2346(3 \%)$ \\
& slab part & 6 & $2305(1 \%)$ & $2289(1 \%)$ \\
\hline
\end{tabular}




\section{Figure 10 - Water absorption (by capillarity) results of (a) cube specimens and (b) cores}

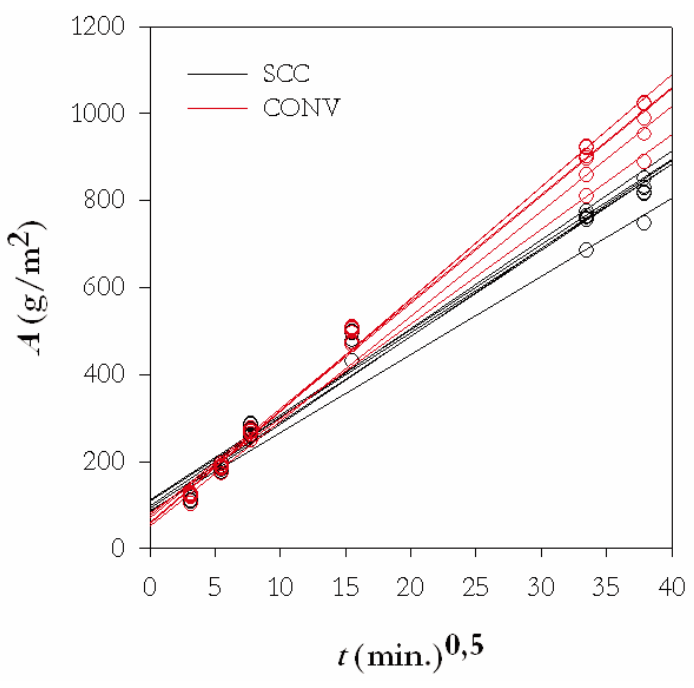

(a)

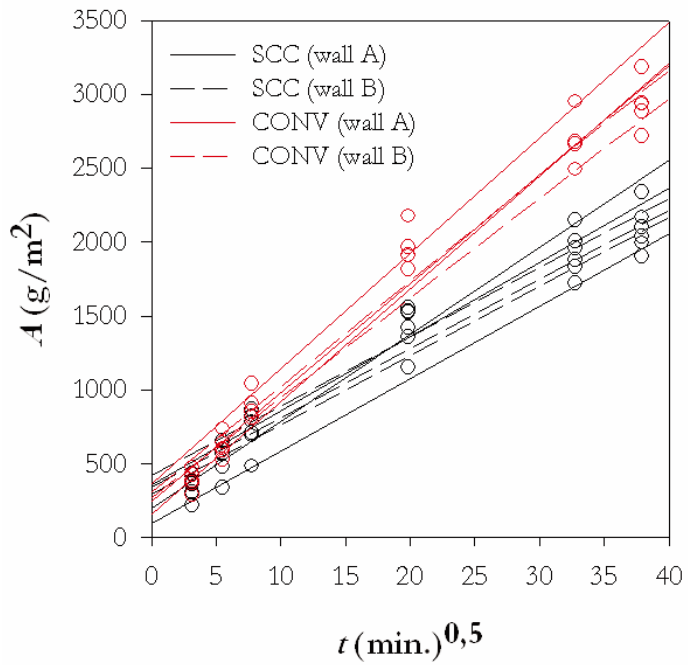

(b) and core samples taken from the box-culvert elements.

Both tests results show that conventional concrete is less resistant to chloride ingress. Insignificant differences were found between cube specimens and core samples results. Based on ASTM C1202, the SCC mixture can be classified as having moderate chloride ion penetrability while conventional concrete mixture presented high

Table 5 - Sorptivity (S), $a 0$ and $R^{2}$ values for cube specimens and cores taken from box-culvert elements

\begin{tabular}{|c|c|c|c|c|c|c|}
\hline \multirow[b]{2}{*}{ Specimen } & \multicolumn{3}{|c|}{ scc } & \multicolumn{3}{|c|}{ CONV } \\
\hline & $\begin{array}{c}S \\
\left(g /\left(m^{2} \times \min ^{1 / 2}\right)\right)\end{array}$ & $\begin{array}{c}a_{0} \\
\left(g / m^{2}\right)\end{array}$ & $\mathbf{R}^{2}$ & $\begin{array}{c}\mathrm{S} \\
\left(\mathrm{g} /\left(\mathrm{m}^{2} \times \mathrm{min}^{1 / 2}\right)\right)\end{array}$ & $\begin{array}{c}a_{0} \\
\left(g / m^{2}\right)\end{array}$ & $\mathbf{R}^{2}$ \\
\hline cube 1 (face X) & 17.90 & 88.96 & 0.981 & 24.60 & 75.66 & 0.994 \\
\hline cube 1 (face Y) & 19.60 & 111.60 & 0.975 & 25.77 & 57.89 & 0.997 \\
\hline cube 2 (face X) & 20.40 & 98.43 & 0.979 & 24.12 & 52.24 & 0.995 \\
\hline cube 2 (face Y) & 20.21 & 85.27 & 0.982 & 24.64 & 71.32 & 0.994 \\
\hline cube 3 (face X) & 19.82 & 92.07 & 0.979 & 25.76 & 60.05 & 0.996 \\
\hline cube 3 (face Y) & 19.40 & 109.38 & 0.970 & 21.74 & 80.94 & 0.992 \\
\hline average (c.v.) & $19.6(5 \%)$ & & & $24.4(6 \%)$ & & \\
\hline core 1 (wall-A) & 50.27 & 354.62 & 0.978 & 78.08 & 368.36 & 0.983 \\
\hline core 2 (wall-A) & 49.03 & 95.67 & 0.996 & 73.80 & 245.38 & 0.990 \\
\hline core 3 (wall-A) & 58.88 & 203.24 & 0.986 & 76.23 & 164.70 & 0.987 \\
\hline average (c.v.) & $52.7(10 \%)$ & & & $76.0(3 \%)$ & & \\
\hline core 1 (wall-B) & 46.61 & 299.13 & 0.986 & 67.36 & 272.66 & 0.985 \\
\hline core 2 (wall-B) & 46.69 & 424.42 & 0.972 & 71.24 & 311.17 & 0.984 \\
\hline core 3 (wall-B) & 46.65 & 345.74 & 0.980 & -- & -- & -- \\
\hline average (c.v.) & $46.6(5 \%)$ & & & 69.3(--) & & \\
\hline
\end{tabular}




\section{Table 6 - Results of ASTM C1202 and NT BUILD 492 test methods obtained on cube specimens}

\begin{tabular}{lcc|} 
cube & $\begin{array}{c}\text { ASTIM C1202 } \\
\text { (coulombs) } \\
\text { face X }\end{array}$ & $\begin{array}{c}\text { NT BUILD 492 } \\
\text { Dns(cm²/s) } \\
\text { face Y }\end{array}$ \\
SCC1 & 2192 & $9.4 \times 10-8$ \\
SCC2 & 2746 & $11.4 \times 10-8$ \\
SCC3 & 3265 & $7.04 \times 10-8$ \\
SCC4 & 2981 & $10.5 \times 10-8$ \\
SCC5 & 2580 & $7.94 \times 10-8$ \\
average (c.v.) & $\mathbf{2 7 5 3 ( 1 5 \% )}$ & $\mathbf{9 . 2 6 \times 1 0 - 8 ~ ( 1 9 \% ) ~}$ \\
CONV1 & 4023 & $14.1 \times 10-8$ \\
CONV2 & 4704 & $14.7 \times 10-8$ \\
CONV3 & 5312 & $14.8 \times 10-8$ \\
CONV4 & 5531 & $15.8 \times 10-8$ \\
CONV5 & 4455 & $12.3 \times 10-8$ \\
average (c.v.) & $\mathbf{4 8 0 5 ( 1 3 \% )}$ & $\mathbf{1 4 . 3 \times 1 0 - 8 ~ ( 9 \% ) ~}$ \\
\hline
\end{tabular}

chloride ion penetrability. Again, the lower water/cement ratio can be responsible for the improved behavior of SCC. Besides, due to increased content and variety of fine materials (cement and limestone filler) and dispersing effect of superplasticizer, as well as, the absence of vibration, an improved microstructure can be obtained, related to higher packing density of paste and reduced size and porosity of the interfacial transition zone (ITZ) [20].

\subsection{Discussion}

Considering hardened SCC and conventional vibrated concrete of similar strength, it can be assumed that properties are comparable and any differences lie in the scattering range for conventional concrete; often, for SCC, lower modulus of elasticity, higher splitting tensile strength, higher shrinkage and better bond to the reinforcement are reported [3], [5], [20], [21] [22] Besides, as it was shown in this study, it is possible to compensate for the lower aggregate content (or higher paste content) in the SCC mixtures with a denser paste to get similar or improved concrete properties.

The transport properties of concrete depend primarily on the paste volume, pore structure of the paste and ITZ between paste and aggregate particles [23]. Although SCC has higher paste volume, the pore structure of the bulk paste and the ITZ are often improved due to the low water-cementitious materials ratios and the use of additions, but not all additions have the same effect. Zhu et al. [23] found that chloride diffusivity was very much dependent on the type of addition used in concrete. The permeability and diffusivity of SCC may be higher or lower than conventionally placed concrete depending on the mixture composition. So far, limited information is available in literature concerning all relevant durability issues, like carbonation, chloride penetration, frost resistance, sulfate attack, thaumasite formation and fire resistance. Concerning this subject, work is currently being carried out under RILEM Technical Committee TC 205-DSC: Durability of self-compacting concrete.

SCC is often produced with low water/cement ratio to get high segregation resistance. This provides potential for high early strength, earlier formwork stripping and quicker mould turnaround, which may be of high interest in precast industry. A positive effect of high segregation resistance of SCC is enhanced homogeneity. Indeed, in this study it was found that concrete strength measured at different locations of the box-culvert element disperses less than in a similar element with conventional concrete. Compaction resulting

Table 7 - Results of ASTM C1202 and NT BUILD 492 test methods obtained on cores taken from box-culvert elements

\begin{tabular}{|c|c|c|c|c|}
\hline \multirow[t]{2}{*}{ core location } & \multicolumn{2}{|c|}{$\begin{array}{l}\text { ASTM C1202 } \\
\text { (coulombs) }\end{array}$} & \multicolumn{2}{|c|}{$\begin{array}{l}\text { NT BUILD } 492 \\
D_{n s}\left(\mathrm{~cm}^{2} / \mathrm{s}\right) \\
\end{array}$} \\
\hline & wall-A & wall-B & wall-A & wall-B \\
\hline $\mathrm{SCCl}$ & 3328 & 3450 & $6.84 \times 10^{-8}$ & $11.7 \times 10^{-8}$ \\
\hline SCC2 & 2965 & 3024 & $9.92 \times 10^{-8}$ & $11.5 \times 10^{-8}$ \\
\hline $\operatorname{scc} 3$ & 2924 & 3273 & $11.10 \times 10^{-8}$ & $9.88 \times 10^{-8}$ \\
\hline SCC4 & 3054 & 3016 & $12.2 \times 10^{-8}$ & $12.6 \times 10^{-8}$ \\
\hline average (c.v.) & $3068(6 \%)$ & $3191(7 \%)$ & $10.0 \times 10^{-8}(23 \%)$ & $11.4 \times 10^{-8}(10 \%)$ \\
\hline CONVI & 4222 & 4059 & $16.4 \times 10^{-8}$ & $14.9 \times 10^{-8}$ \\
\hline CONV2 & 4005 & 3987 & -- & $15.9 \times 10^{-8}$ \\
\hline CONV3 & 4427 & 5099 & $16.0 \times 10^{-8}$ & $15.1 \times 10^{-8}$ \\
\hline CONV4 & -- & 4390 & $15.7 \times 10^{-8}$ & $16.5 \times 10^{-8}$ \\
\hline average (c.v.) & $4218(--)$ & $4384(12 \%)$ & $16.0 \times 10^{-8}(--)$ & $15.6 \times 10^{8}(5 \%)$ \\
\hline
\end{tabular}


from external vibration is uneven depending on the vibration sources. SCC provides potential for a superior level of homogeneity and durability for the structure.

\section{Conclusions}

Based on presented results the following conclusions can be drawn:

1. The SCC mixture optimized in the laboratory had to be adjusted during full-scale testing, at the precast factory, to attend to the differences in the mixing efficiency, to achieve high segregation resistance and sufficient deformability of fresh concrete;

2. Precast concrete factories are specially suited for the use of self-compacting concrete but some adjustments in installations and equipment might be necessary in order to optimize casting procedures and maximize benefit from this technology;

3. In spite of the lower coarse aggregate content of SCC, when compared with conventional concrete, with a reduction in water/cement and water/fines ratios, better mechanical properties and resistance to the ingress of aggressive agents were obtained;

4. The differences between mix proportions of the SCC and conventional concrete lead to an $18 \%$ increase of materials cost for SCC and mixing time, at the precast factory, was twice the time used for conventional concrete. Nevertheless, it is possible to reduce the mixing times by increasing the mixing speeds or by changing the configuration of the paddles in the mixer. A suitable mixing protocol is to be established for each individual precast factory. This had not been done in this precast factory by the time of the first full-scale tests described here.

5. Properly proportioned, produced and placed SCC is generally more compact and homogeneous than equivalent vibrated concrete, thus leading to enhanced strength and durability performance of concrete structures when made with SCC.

\section{Acknowledgements}

This research work was financed by Adl- Innovation Agency and carried out under the scope of a Portuguese research project "BACPOR" in direct co-operation with local industry, namely, Mota-Engil Engenharia, Sika and Maprel. This research was also supported by FCT Research Grants SFRH/BD/25552/2005 and SFRH/BD/25123/2005.

\section{References}

[01] Skarendhal A. The present - The future. In: Wallevik O, Nielsson I, editors. Proceedings of the 3rd International RILEM Symposium. Reykjavik, Iceland. 2003. p. 6-14.

[02] Repette W. Self-compacting concrete - A Labor cost evaluation when used to replace traditional concrete in building construction. In: De Schutter G., Boel V., editors. Proceedings of the 5th International RILEM Symposium. Ghent, Belgium. 2007. p. 1001-1006.

[03] EFNARC. The European Guidelines for Selfcompacting Concrete. www.efnarc.org. 15-06-2005 11:00.
[04] Japan Society of Civil Engineers. Recommendation for Construction of Self-Compacting Concrete. Proceedings of the International Workshop on Self-compacting Concrete. Kochi, Japan. 1998. p. 417-437.

[05] Walraven J. Self-compacting concrete: Challenge for designer and researcher. In: Shah SP, editor. Proceedings of The Second North American Conference on the Design and use of Self-Consolidating Concrete and the Fourth International RILEM Symposium on Self-compacting Concrete. Chicago, United States of America. 2005. p. 431-445.

[06] Nunes S. Experimental study and numerical modelling of self-compacting concrete. In: Walraven J., Blaauwendraad J., Scarpas T., Snidjer B., editors. Proceedings of The 5th International PhD Symposium in Civil Engineering. Delft, The Netherlands. 2004. p. 857-865.

[07] Nunes S., Oliveira P. M., Coutinho, J. S., Figueiras J. Interaction diagrams to assess SCC mortars for different cement types. Construction and Building Materials 2009; 23: 1401-1412.

[08] Nunes S., Figueiras H., Coutinho J. S., Figueiras J. Relatório de Execução Material, $4^{\circ}$ Semestre de Actividades, Consórcio BACPOR. 2005. (in Portuguese)

[09] Cussigh F., A set of European standards for SCC. In: De Schutter G., Boel V., editors. Proceedings of the 5th International RILEM Symposium on Selfcompacting Concrete. Ghent, Belgium. 2007. p. 1041-1047.

[10] Nunes S., Figueiras H., Coutinho J. S., Figueiras J. SCC implementation in the Portuguese industry. In: Shah SP, editor. Proceedings of The Second North American Conference on the Design and use of Self-Consolidating Concrete and the Fourth International RILEM Symposium on Self-compacting Concrete. Chicago, United States of America. 2005. p. 1165-1171.

[11] Nunes S., Figueiras H., Oliveira P. M., Coutinho J. $\mathrm{S}$., Figueiras J. A methodology to assess robustness of SCC mixtures. Cement \& Concrete research 2006; 36:2115-2122.

[12] Mansur M. A., ASCE M., Islam M. M. Interpretation of concrete strength for non-standard specimens. Journal of Materials in Civil Engineering 2002; 151-155.

[13] Neville AM. Properties of concrete. England: Longman, 1998.

[14] Coutinho J. S. The combined benefits of CPF and RHA in improving the durability of concrete structures. Cement \& Concrete composites 2003; 25:51-59.

[15] RILEM TC116-PCD. Permeability of concrete as a criterion of its durability, C: Determination of the capillary absorption of water of hardened concrete. Materials and Structures 1999; 32:178-179.

[16] Sonebi M., Bartos P. J. M., Zhu W., Gibbs J. Tamini A. Final Report of Task4: Properties of Hardened 
Concrete, Rational production and Improved Working Environment Trough Using Self Compacting Concrete. Brite Euram Project BRPR-CT96-0366, http://scc.ce.luth.se, 15-08-2001 10:30.

[17] ASTM C 1202. Standard test method for electrical indication of concrete's ability to resist chloride ion penetration. American Society for Testing Materials. 1997.

[18] NT BUILD 492. Concrete, mortar and cement-based materials: Chloride migration coefficient from nonsteady-state migration experiments. NORDTEST. 1999.

[19] Especificação LNEC E 463. BETÃO. Determinação do coeficiente de difusão dos cloretos por ensaio de migração em regime não estacionário. 2004.

[20] Klug Y., Holschemacher K. Comparison of the hardened properties of self compacting and normal vibrated concrete. In: Wallevik $O$ and Nielsson I, editors. Proceedings of the 3rd International RILEM Symposium. Reykjavik, Iceland. 2003. p. 596-605.

[21] Domone P. A review of the hardened mechanical properties of self-compacting concrete. Cement and Concrete Composites 2007; 29(1): 1-12.

[22] Valcuende M., Parra C. Bond behaviour of reinforcement in self-compacting concretes. Construction and Building Materials 2009; 23: 162-170.

[23] Zhu W., Quinn J., Bartos P. M. J. Transport properties and durability of self-compacting concrete. In: Ozawa K., Ouchi M., editors. Proceedings of the 2nd International RILEM Symposium Self-compacting Concrete. Tokyo, Japan. 2001. p. 451-458. 